\title{
A content analysis and evaluation of outcomes of specialty theses in dentistry
}

\author{
๑DSüleyman Kutalmış Büyük1, @Recep Türken², @Serdar Akarsu ${ }^{3}$ \\ ${ }^{1}$ Ordu University, Faculty of Dentistry, Department of Orthodontics, Ordu, Turkey \\ ${ }^{2}$ Ordu University, Faculty of Dentistry, Department of Prosthodontics, Ordu, Turkey \\ ${ }^{3}$ Ordu University, Faculty of Dentistry, Department of Restorative Dentistry, Ordu, Turkey
}

Cite this article as: Büyük SK, Türken R, Akarsu S. A content analysis and evaluation of outcomes of specialty theses in dentistry. J Health Sci Med 2021; 4(4): 412-415.

\begin{abstract}
Aim: This study aimed to evaluate the characteristics of dentistry residents and their supervisors involved in the publication of dentistry specialty theses in Turkey.

Material and Method: The dentistry specialty theses uploaded to the Council of Higher Education (YÖK) National Thesis Centre website during 2015-2019 were researched, and 1381 theses were identified and selected.

Results: One thousand three hundred and forty theses were completed at state universities and 41 at foundation universities. While 477 of the theses were prepared by male residents, 904 were prepared by female residents. Four hundred eighteen of the theses were supervised by assistant professors, 413 by associate professors, and 550 by professors. Most of the theses were completed at Hacettepe University. The greatest number of theses were in orthodontics $(n=341)$ and the fewest in oral and maxillofacial radiology $(n=89)$. Published theses accounted for $23.4 \%$ of the total, and $15.4 \%$ were in Science Citation Index Expanded journals.

Conclusion: This cross-sectional study revealed that dentistry specialty theses in Turkey contributed to national and international literature.
\end{abstract}

Keywords: Dentistry, graduate thesis, content analysis, article

\section{INTRODUCTION}

In Turkey, oral and maxillofacial radiology, oral and maxillofacial surgery, orthodontics, periodontology, pedodontics, restorative dentistry, endodontics and prosthodontics are postgraduate programs within departments of clinical sciences in dentistry faculties. Nowadays, to receive the title of specialist dentist in Turkey, each candidate must produce a dental specialist thesis on a chosen topic under the guidance of a faculty advisor and must successfully defend the thesis before a panel of examiners.

Students specializing in dentistry are required to prepare a thesis on a subject related to their specialty training before they can take the final examination and earn the title of specialist dentist. Thesis studies help residents gain scientific research skills by creating hypotheses in subjects they are curious about and collecting and analyzing data on their chosen topics. Although thesis studies are the building blocks of graduate education, their results should also be shared with the world of science. For this purpose, the publication of results obtained from postgraduate theses in national or international refereed journals can indicate research quality. (1-5)

This study evaluates the journal publication rates of the departments, universities, and thesis supervisors for dentistry specialty theses completed in our country between 2015 and 2019.

\section{MATERIALS AND METHODS}

Ethics committee approval for this study was given by Ordu University Clinical Research Ethics Committee (Date: 03/09/2020, Decision No: 2020/175). All procedures were carried out in accordance with the ethical rules and the principles of the Declaration of Helsinki. In this study, all dentistry theses uploaded to the Council of Higher Education National Thesis Center website (https://tez.yok. gov.tr/UlusalTezMerkezi/) between 2015 and 2019 were researched, and 1,381 theses were identified and selected. The registration of names and information for the relevant 
theses in the Higher Education Council Thesis Center was carried out by a single researcher (R.T.) in September 2020.

Next, for each thesis we evaluated its publication date, the university and department where the thesis was done, academic title of the thesis supervisor, co-advisor status, type of thesis subject, whether the thesis was published in a refereed scientific journal, length of the published article, journal index and database, and whether the thesis student is continuing his or her academic career. To this end, a thesis student, supervisor and two expert researchers (R.T. and S.A.) searched Google Scholar (https://scholar.google. com) and PubMed (www.ncbi.nlm.nih.gov/pubmed) databases for articles produced from the related theses. For female thesis students, the search also considered potential surname changes due to marital status. If there was no match between the title of the published article and the thesis, the relevant thesis and article abstract were carefully scanned and checked.

\section{RESULTS}

Within the scope of our study, all presentations were made between 2015 and 2019 and were successfully defended, and 1,381 dentistry specialization theses registered by YÖK Thesis Center were evaluated. While 477 theses were prepared by male students, 904 were prepared by female students. The number of dentistry specialty theses per year is shown in Figure 1. As is evident, the works range in length from 48 to 408 pages.

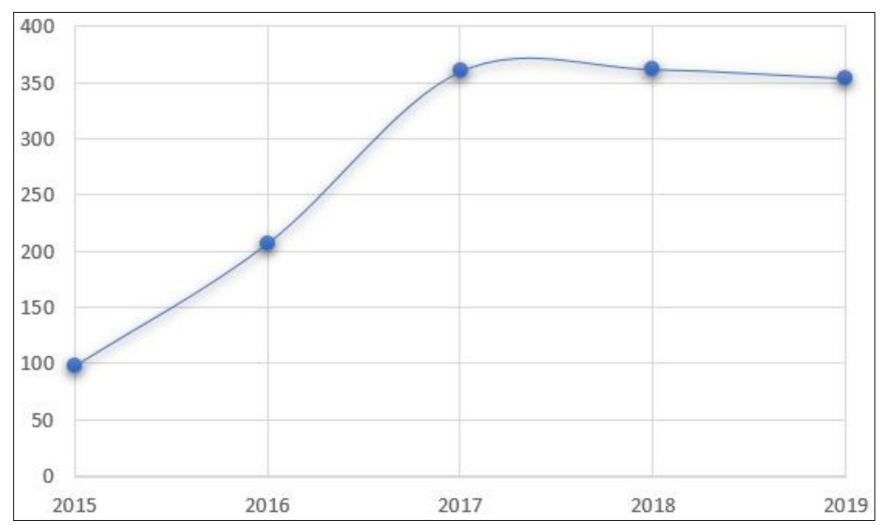

Figure 1. Distribution of theses by years.

Four hundred eighteen of the theses were supervised by faculty members, 413 by associate professors, and 550 by professors. Also, co-advisors participated in the supervision of 30 theses. These co-advisors consisted of 12 physician lecturers, four associate professors, and 14 professors.

Thirty-six Turkish state universities and three foundation universities produced dentistry specialty theses between 2015 and 2019 (Table 1). The greatest number were completed at Hacettepe University (99), followed by Ondokuz Mayıs (88) and Atatürk University (87).

\section{Table 1. Distribution of theses by universities}

\begin{tabular}{|c|c|c|}
\hline Number & University & $\begin{array}{l}\text { Number of } \\
\text { specialty thesis } \\
\text { in dentistry }\end{array}$ \\
\hline 1 & Ankara Üniversitesi & 47 \\
\hline 2 & $\begin{array}{l}\text { Afyon Kocatepe/Afyonkarahisar } \\
\text { Sağllk Bilimleri Üniversitesi }\end{array}$ & 7 \\
\hline 3 & $\begin{array}{l}\text { Aydın Adnan Menderes } \\
\text { Üniversitesi }\end{array}$ & 22 \\
\hline 4 & Akdeniz Üniversitesi & 39 \\
\hline 5 & Atatürk Üniversitesi & 87 \\
\hline 6 & Başkent Üniversitesi & 14 \\
\hline 7 & $\begin{array}{l}\text { Bolu Abant İzzet Baysal } \\
\text { Üniversitesi }\end{array}$ & 28 \\
\hline 8 & Bezmi Alem Vakıf Üniversitesi & 24 \\
\hline 9 & Bülent Ecevit Üniversitesi & 31 \\
\hline 10 & Cumhuriyet Üniversitesi & 65 \\
\hline 11 & Çukurova Üniversitesi & 40 \\
\hline 12 & Dicle Üniversitesi & 43 \\
\hline 13 & Ege Üniversitesi & 36 \\
\hline 14 & Erciyes Üniversitesi & 31 \\
\hline 15 & Eskişehir Osmangazi Üniversitesi & 25 \\
\hline 16 & Firat Üniversitesi & 1 \\
\hline 17 & GATA Üniversitesi & 11 \\
\hline 18 & Gazi Üniversitesi & 14 \\
\hline 19 & Gaziantep Üniversitesi & 32 \\
\hline 20 & Gaziosmanpaşa Üniversitesi & 26 \\
\hline 21 & Hacettepe Üniversitesi & 99 \\
\hline 22 & İnönü Üniversitesi & 33 \\
\hline 23 & İstanbul Üniversitesi & 43 \\
\hline 24 & İzmir Katip Çelebi Üniversitesi & 25 \\
\hline 25 & Karadeniz Teknik Üniversitesi & 48 \\
\hline 26 & Kırıkkale Üniversitesi & 54 \\
\hline 27 & Kocaeli Üniversitesi & 39 \\
\hline 28 & Marmara Üniversitesi & 54 \\
\hline 29 & İstanbul Medipol Üniversitesi & 16 \\
\hline 30 & Necmettin Erbakan Üniversitesi & 22 \\
\hline 31 & Ondokuz Mayıs Üniversitesi & 88 \\
\hline 32 & Ordu Üniversitesi & 33 \\
\hline 33 & Pamukkale Üniversitesi & 10 \\
\hline 34 & $\begin{array}{l}\text { Rize Recep Tayyip Erdoğan } \\
\text { Üniversitesi }\end{array}$ & 9 \\
\hline 35 & Sağlık Bilimleri Üniversitesi & 16 \\
\hline 36 & Selçuk Üniversitesi & 81 \\
\hline 37 & Süleyman Demirel Üniversitesi & 71 \\
\hline 38 & Van Yüzüncüyıl Üniversitesi & 16 \\
\hline 39 & Yeditepe Üniversitesi & 1 \\
\hline
\end{tabular}

The distribution of theses by department is shown in Figure 2. The greatest number of dentistry specialty theses were produced in orthodontics $(n=341)$ and the fewest in oral and maxillofacial radiology $(n=89)$. When the theses were examined according to research type, prospective-clinical and epidemiological studies were the most common (Table 2). 


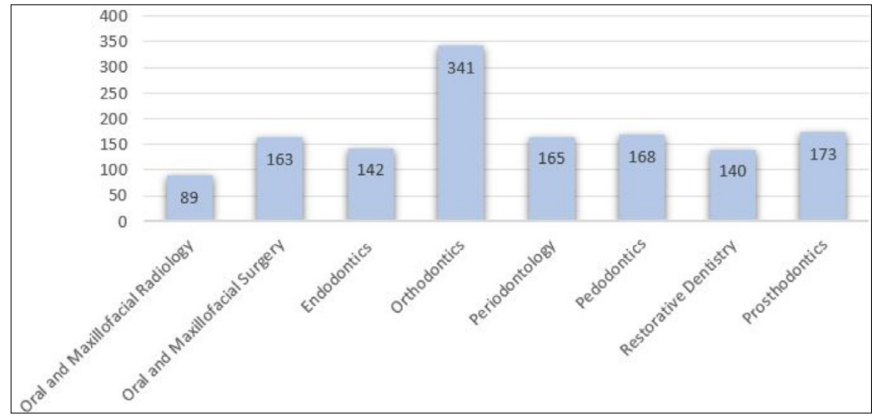

Figure 2. Distribution of the theses according to the departments.

Table 2. Types of research in theses.

\begin{tabular}{|lc|}
\hline Research type & Number \\
\hline Survey study & 72 \\
Clinic-epidemiologic study & 511 \\
Animal study & 60 \\
In-vitro study & 478 \\
Radiographic and retrospective study & 214 \\
Finite element method study & 46 \\
\hline
\end{tabular}

An evaluation of the publication rate of theses found that $323(23.4 \%)$ of the 1,381 evaluated theses had been turned into published scientific articles. The distribution of these articles according to the published indexes can be seen in Figure 3. While 15.4\% of the theses were published in journals covered by Science Citation Index-Expanded (SCI-E), $4.6 \%$ were published in journals covered by TR Index. The number of published theses by department can be seen in Figure 4.

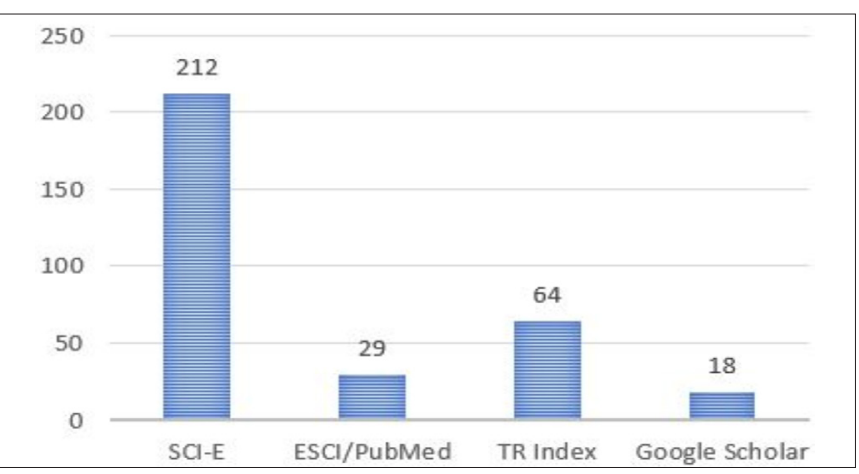

Figure 3. Distribution of the number of theses to be converted into articles in journals in national or international indexes.

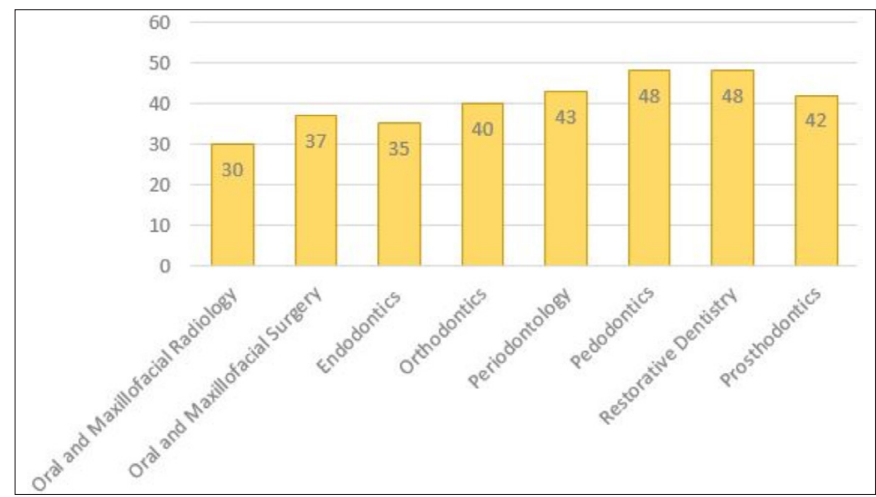

Figure 4. Distribution of the number of theses to articles according to the departments.

\section{DISCUSSION}

The first examination for the specialization training in dentistry was held in April 2012, and those who successfully submitted their theses from the relevant departments and succeeded in their final exams earned the title of specialist dentist. In this context, the dentists who won the relevant department in April 2012, which was the first exam in our country in which specialist dentists were determined, through a central examination in the Department of Clinical Sciences, were determined as 3 or 4 years. have been. For this purpose, in this study, specialty theses in dentistry between 2015 and 2019 were evaluated (6).

Specialty theses are one of the most important parts of dentistry specialty education. The specialty thesis aims to enable the trained resident to conduct scientific research. Thus, dentists who have specialized training will learn to interpret the literature, be aware of current international developments, apply reliable treatment methods to their patients as necessary, and plan the path they will follow when designing a scientific study. In addition, they will contribute to the development level of our country by laying the groundwork for scientific studies they conduct nationally and internationally.

Our study is the first and only one to evaluate specialty theses in dentistry in Turkey. In this context, using the same standards, it is possible to compare them with the studies evaluating medical specialty theses produced in Turkey. Erim and Petekkaya (7) evaluated 910 specialty theses in psychiatry in our country between 1981 and 2018. In their study, the average rate of publication of theses was $37.7 \%$, while the rate of publication in SCI and SCI-E index journals was $28.5 \%$. Sipahi et al. (4) examined the publication rates of medical specialty and doctoral theses in medical microbiology, clinical microbiology and infectious diseases in international journals; they determined that $94(11.4 \%)$ of a total of 824 theses became international publications. In our study, 323 of the 1,381 specialty theses $(23.4 \%)$ were published as national or international journal articles. In a study examining specialty theses in family medicine between 1981 and 2008, 2.1\% were published in journals covered by SCI-E (8). In contrast, the rate of SCI-E journal publication of theses produced in the urology departments was $32.7 \%$ (9); the corresponding rates were $18 \%$ (10) for neurosurgery and $18.5 \%$ (11) for eye diseases and surgery. In our study, $212(15.4 \%)$ of the articles obtained from specialty theses in dentistry were published in journals covered by SCI-E.

In our study, it is instructive to evaluate the number of theses uploaded to the YÖK National Thesis Center website relative to the number of dentistry specialty theses. Although such a well-established institution as 
Gazi University had over 50 residents from 2012 to 2015, the fact that only 14 dentistry theses were included in the YÖK Thesis Center's database is probably because the theses were not entered into the system by the relevant administrative staff. Even though Mustafa Kemal University has produced at least one dentistry specialty student, there is no specialist thesis in dentistry at the YÖK Thesis Center from this university. In this regard, the administrators of faculties of dentistry should follow the relevant units closely and ensure that the theses completed in their faculties are entered into the system in a timely manner.

\section{CONCLUSIONS}

Although the total number of specialty theses in dentistry is not high, the field has yielded an encouraging output of articles in national and international journals. In order to improve the scientific level of our country by increasing the publication rate, institutions should support the academic education of specialty students to the same degree as their clinical education. Thesis advisors should closely follow the thesis preparation process of research assistants specializing in dentistry and play an important role in transforming the results of theses into internationally published articles. To this end, research assistants specializing in dentistry should devote more time to scientific research throughout their degree programs and complete their education with an academic perspective.

\section{ETHICAL DECLARATIONS}

Ethics Committee Approval: This study was approved by Ordu University, Clinic Research Ethic Committee (Date: 03/09/2020, Decision No: 2020/175).

Informed Consent: Not applicable.

Conflict of Interest Statement: The authors have no conflicts of interest to declare.

Financial Disclosure: The authors declared that this study has received no financial support.

Author Contributions: All authors declare that they have all participated in the design, execution, and analysis of the paper, and that they have approved the final version.

\section{REFERENCES}

1. Nieminen P, Sipilä K, Takkinen HM, Renko M, Risteli L. Medical theses as part of the scientific training in basic medical and dental education: experiences from Finland. BMC Med Educ 2007; 7: 51.

2. Brunod I, Rességuier N, Fabre A. Medical thesis publication and academic productivity of pediatric residents at the Medical University of Marseille: Associated factors and evolution over 20 years. Arch Pediatr 2020; 27: 408-15.

3. Tosuntaş ŞB, Emirtekin E, Süral İ. Eğitim ve öğretim teknolojileri konusunda yapilan tezlerin incelenmesi (2013-2018). Yüksekögretim ve Bilim Derg 2019; 9: 277-86.
4. Sipahi OR, Serin DC, Pullukçu H, et al. Publication rates of Turkish medical specialty and doctorate theses on medical microbiology, clinical microbiology and infectious diseases disciplines in international journals. Mikrobiyol Bul 2014; 48: 341-5.

5. Karaman S, Bakırcı F. Türkiye'de lisansüstü eğitim: sorunlar ve çözüm önerileri. Sosyal Bilimler Araştırmaları Derg 2010; 2: 94 114.

6. Tıpta ve Diş Hekimliğinde Uzmanlık Eğitimi Yönetmeliği T.C. Resmi Gazete. Tarihi: 26.04.2014. Sayı:28983.

7. Erim BR, Petekkaya S. Türkiye'de psikiyatri alanında 1981-2018 yılları arasında yapılmış uzmanlık tezlerinin değerlendirilmesi. Türk Psikiyatri Derg 2020; 31: 1-8.

8. Yaman H, Kara IH, Baltaci D, Altug M, Akdeniz M, Kavukcu E. Qualitative evaluation of theses written in area of family medicine in Turkey. Konuralp Tip Derg 2011; 3: 1-6.

9. Yüksel M, İpekçi T, Tunçkıran A. Publication rates of dissertations written in medical faculties of Turkey in the field of urology between the years 2008, and 2011, and citation analysis: A crosssectional study. Turk J Urol 2018; 44: 341.

10.Öğrenci A, Ekşi MŞ, Özcan-Ekşi EE, Koban O. From idea to publication: Publication rates of theses in neurosurgery from Turkey. Neurologia i Neurochirurgia Polska 2016; 50: 45-47.

11. Bayramlar H, Karadag R, Kanra Gürtürk AY, Öçal A, Dağ Y, Sarı Ü. Publication patterns of ophthalmology residency dissertations in Turkey. Eur J Gen Med 2015;12: 213-6. 